Geografia e Ordenamento do Território, Revista Eletrónica

Centro de Estudos de Geografia e Ordenamento do Território

http://cegot.org

ISSN: 2182-1267

Centro de Estudos de Geografia

e Ordenamento do Território

Hall, P.

University College London - UCL

p.hall@ucl.ac.uk

\title{
Refreshing the parts that other transport cannot reach
}

Referência: Hall, P. (2013). Refreshing the parts that other transport cannot reach. Revista de Geografia e Ordenamento do Território, n.ㅇ 3 (Junho). Centro de Estudos de Geografia e Ordenamento do Território. Pág. 7 a 21.

We're all familiar with being told that on a global scale the rural world is going to town. In the developing world, in the Middle East and in much of the Far East and in Latin America, that is undoubtedly true. And throughout the world people are coming together on a vast scale. Travelling on the London Underground and listening to all the many tongues that people are using as they talk on their mobile phones, you could well believe that we have latter-day Towers of Babel in some of our great European cities.

But there is a paradox here, because just as people are coming into cities, others are leaving them - as they've been doing for a very long time. The late Martin Mogridge showed some time ago that for 200 years London had been exporting population to its immediately surrounding ring and then into increasingly distant rings. That process of decentralisation, repeated widely elsewhere, is continuing, and it has generally 
resulted in a shift from more to less sustainable forms of transport, especially automobile dependence.

However, many of the cities themselves are busy building sustainable public transport networks - and here London can pat itself on the back as it now has a superb public transport system. It wasn't always so superb, but it's now running at perhaps the highest efficiency ever experienced, with, for example, the Docklands Light Railway running at an impressive $99.2 \%$ of trains on time.

This improvement is happening very widely, especially in Europe, which is taking a lead in sustainable public transport, extending from the core cities into the surrounding metropolitan areas. But, crucially, beyond the termini of these metro, tram or light rail systems, the 'peri-urban peripheries' remain highly auto dependent. Here, the answer (although perhaps not a complete answer) is something we can call the 'Heineken model', refreshing parts that public transport hitherto has not successfully served. That means developing innovative transport options - tram-trains and bus rapid transit - and using them as transport-oriented corridors, as the basis for new planned urban extensions.

\section{Urban dynamics}

First, the facts: what is happening in our cities? In the US there has been huge excitement over a report from William Frey at the Brookings Institution, published last spring (Frey, 2012), which found that very recently the primary cities in the largest metropolitan areas have been growing faster than their suburbs (Frey, 2012) - not very much faster, but there is a significant shift (Fig. 1). Frey's report shows that this reverses a 90-year trend: US cities have not grown faster than their suburbs since the 1920s. Frey thinks that part of the explanation is the drastic drop in suburban house construction after the 2008 crisis - but he also thinks that it represents a lifestyle change: young people are reacting against the suburban lifestyles of their parents and seeking a life in the city. 
Fig. 1 Population Trends, USA, 2010-11

Percent of U.S. Primary City and Suburb population growth rates in five metro areas

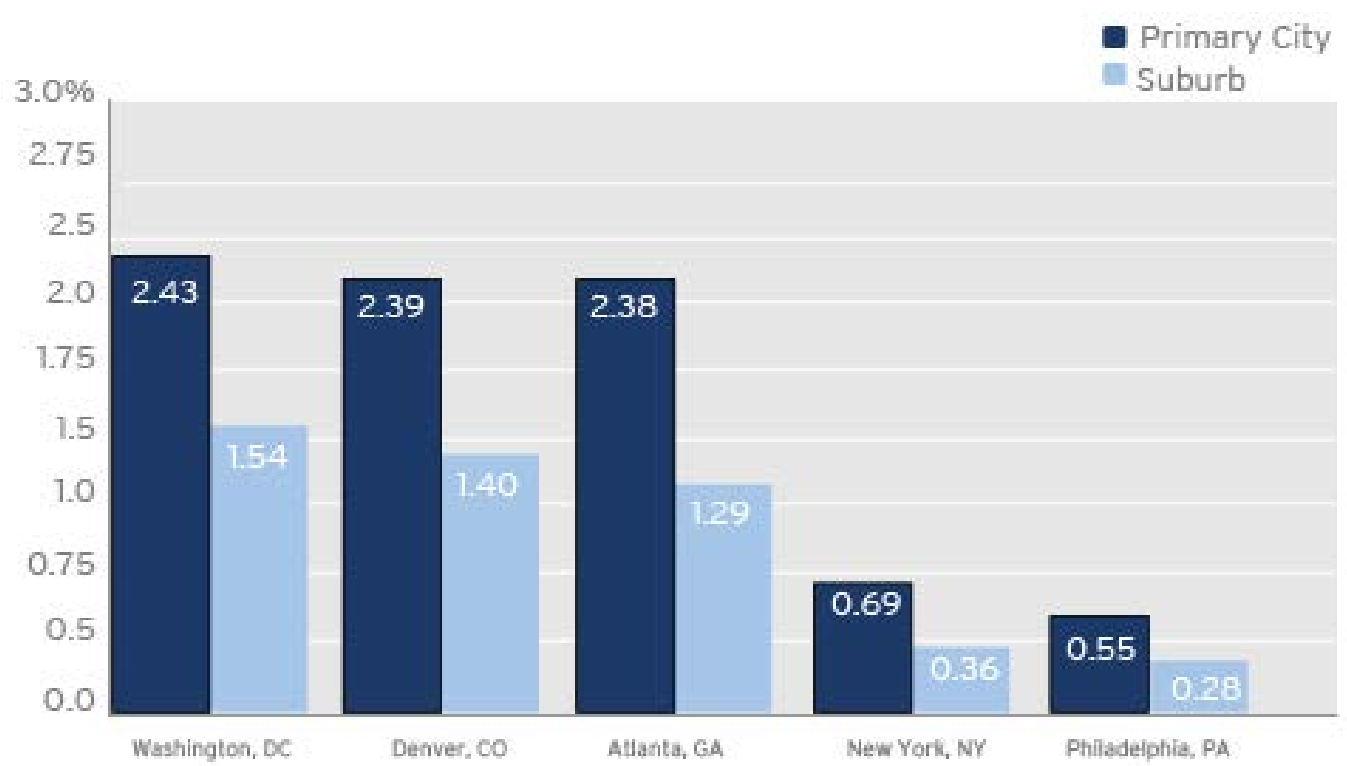

Source: Brookings Institution

In the UK, the 2011 Census shows that there too the cities are growing, too. London's population has increased by nearly 1 million people -1.1 million in ten years. Even if that figure isn't totally reliable (many demographers believe the 2001 Census was an under-count), there has undoubtedly been a huge increase. This was driven by immigration from abroad, both from EU and non-EU countries. But growth has occurred elsewhere: in Manchester, Milton Keynes, Leicester and Peterborough. Most are in the South of England, including many smaller places in what we can think of as an extended London mega-city region, but nonetheless there does seem to be a reversal of a long observable trend in the UK, too. However, equally importantly, many other cities are declining, typically the old industrial cities in the rust-belt areas of the Midlands and the North of England. Here we are seeing the emergence of an 'archipelago economy', a term invented by a French urbanist, Pierre Veltz, in 1996 and recently borrowed by Professor Danny Dorling, a geographer at the University of Sheffield (Veltz, 2004), whereby a very big global city, such as London, grows into a 'mega-city region', with only isolated islands of growth outside it (in the UK mainly in core cites such as Manchester and Leeds), surrounded by vast seas of decline. 
It needs stressing that growth and decline can happen simultaneously. Research has shown that in the EU there is a very pervasive phenomenon of relative decentralising: both the core city and the wider urban area are growing, but the growth is higher in the outer areas than in the core city.

\section{Transport trends}

Why is this important? Two transport research reports are relevant here. One from the UK Office for National Statistics, published in 2008 (Littlefield and Nash, 2008) reveals the high degree of car dependence in areas of the South East of England beyond about 80 kilometres from the centre of London. Fig. 2, taken from the report, shows that the only areas in the South East that have a significant dependence on public transport are London (especially) and the cores of a very few other areas, with arms of public transport dependence going out along the main railway lines. But those areas where the car rules are precisely the areas to which people are moving out from London.

The second, On the Move (Vine and Jones, 2012), published in December 2012 is a response to a thesis developed by Professor Phil Goodwin, who has argued very persuasively that in the UK car use peaked around ten years ago and is actually now in decline. The new research finds that the 'peak car' theory is a myth, with cars continuing to account for no less than $79 \%$ of total movements. The big exception is London, where car use has indeed been declining - back to that superb public transport system - but London is out of line with the rest of the UK. But even in London the picture is not straightforward, as the Mayor's Outer London Commission report, in 2010, showed (The Mayor's Outer London Commission: Report. Mayor of London, Jun. 2010). Although Inner London is highly public transport dependent, the outer areas, the suburbs developed between the two world wars, which also have excellent public transport, are very largely car dependent. Public transport, even in London, is not at all universal. 
Fig. 2 Commuting by public transport, South East England

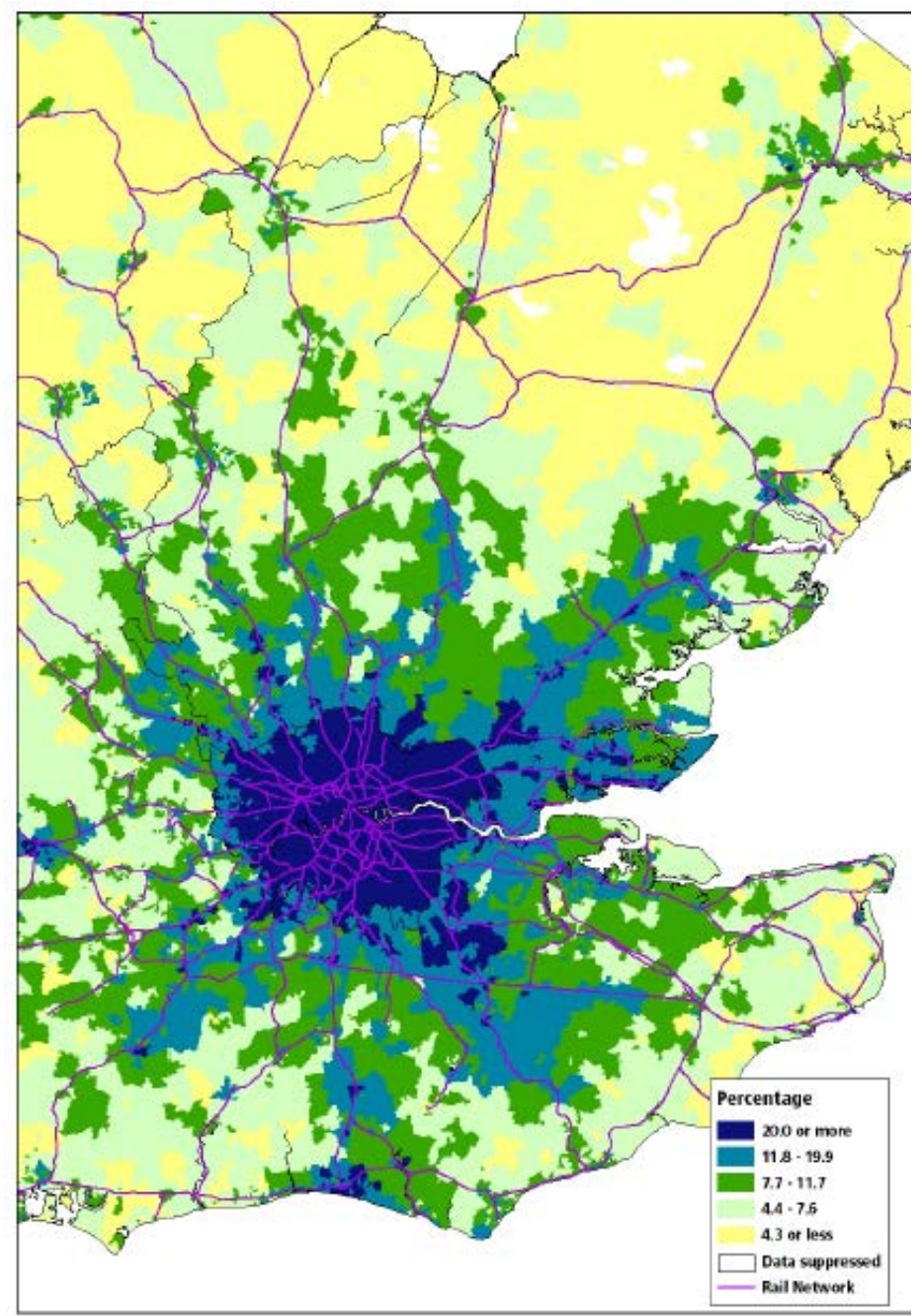

Source: Office for National Statistics

The importance of this is that all over Europe, there is a tendency for people to move further and further out, even if many of them continue to hold jobs in the central city. In Sweden a mega-city region has developed in the Mälar region around Stockholm in the last 25 years, aided by very intelligent investments in rail-based public transport which have brought surrounding smaller cities like Eskilstuna and Örebro into closer daily connection with jobs in the centre of Stockholm. But the result is increasing lengths of longer-distance journeys - a general feature throughout Europe. 


\section{Exemplars of sustainable urban transport}

Some European cities have been setting splendid examples of how to develop more sustainable urban public transport systems (Hall, 2013). In Freiburg, a small city of 200,000 people in the south west corner of Germany, the eco-movement that grew up in opposition to nuclear power in the 1970s has in effect been running the city, very effectively and often in coalition, for some 30 years, supported a splendid city planning office run by the legendary Wolf Daseking (now retired and an Honorary Professor at $\mathrm{UCL}$ ). Here the new suburb of Vauban, built at moderate densities and connected by a 15-minute tram ride from the centre of the city, has the tram running along the central axis of the new suburb and new residential development on either side. Vauban features an extraordinary combination of massing of the built blocks in moderate densities, typically three- to five-story houses and apartments around open space, built to designs finalised, within city guidelines, by the residents themselves in socalled building groups.

Ypenburg, just outside The Hague in the Netherlands, is, as the Dutch call it, an urban extension to The Hague, recently completed and again developed at moderately but not exceedingly high densities. Separated from the built-up mass of The Hague only by a motorway (which surrounds it on two sides - not quite as sustainable as one would like), it is served by two tram lines, one of which in turn is connected to a new tram-train system, the RandstadRail, on the edge of the development - a remarkable level of public transport service.

Vauban and Ypenburg are remarkable developments, but equally remarkable things are happening elsewhere. Montpellier, the fastest growing French city over the last half-century, has opened three long tram lines running from edge to edge and now outside the city altogether, plus a fourth line which acts as a circular line connecting them up around the city centre ${ }^{1}$. These lines promote urban development and regeneration within the Montpellier agglomeration on a very large scale, including a new - now the main - university campus to the east of the city centre, in an area

\footnotetext{
${ }^{1}$ See P. Hall: 'Lifestyle lines and dynamic decentralisation'. Town \& Country Planning, 2012, Vol. 81, Mar., 114-5
} 
previously almost undeveloped, causing it to become a very large-scale extension of the historic mediaeval city centre. But rather remarkably the tram then runs on to terminate at a development called Odyssseum, an amazing combination of leisure shopping and entertainment facilities - in effect, a second city centre. And this will be the location of a new TGV station on the main line from Paris to Barcelona.

Most remarkably, line 3, which opened in April 2012, served by trams in a somewhat surreal livery designed by dress designer Christian Lacroix, as part of a deliberate job of image creation, will serve as basis for a new growth corridor - five kilometres long, and eventually perhaps 25 kilometres long, if and when it gets as far as the 1970 s seaside resort development of La Grande-Motte - with huge plans for new homes, offices, public buildings, all largely outside the Montpellier city limits. This is possible because, as long as 40 years ago, France created bodies which united the often small communes in French urban areas into new agglomeration communities, of which this is one. Not merely in Montpellier but also in other places in France such as Strasbourg, these are the vehicles for creating new transport links and in particular for bringing together investment in tramways and new investment in urban development.

\section{Transport options for peri-urban areas}

The Montpellier tram lines may eventually run 25 kilometres beyond the city, but the key question is: what is the limit to which systems like this can extend, and can extensive systems be replicated a widespread scale? Rather remarkable new research by Xavier Desjardins, a geographer at the Panthéon-Sorbonne University in Paris (Desjardins, 2012), shows that in three French tramway cities - Strasbourg, Amiens, and Rennes - the so-called peri-urban belt is now a very important part of the whole agglomeration. Furthermore, in all these cities, to varying degrees, a large proportion of the people living in these peri-urban belts are outside the range of easy access by rail. In other words, they are car dependent.

Desjardins' research shows that between the most recent two French censuses, in Amiens and Rennes the population in the areas outside the rail corridors grew much 
faster than the population in the areas inside the rail corridors (Fig. 3). In other words, in Amiens and in Rennes the people outside the central city are becoming ever more car dependent. Strasbourg provides a contrast: there is growth in the population outside the rail corridor, but the growth inside the rail corridors is much more significant. And this is due to a conscious effort on Strasbourg's part, or rather on the part of the communes outside Strasbourg, who are granting a higher share of building permits inside the rail corridors compared with the other two cities, who don't seem to care very much - or rather their often small communes don't seem to care very much.

Fig. 3 French cities: Share of population growth inside/outside rail corridors

Amiens

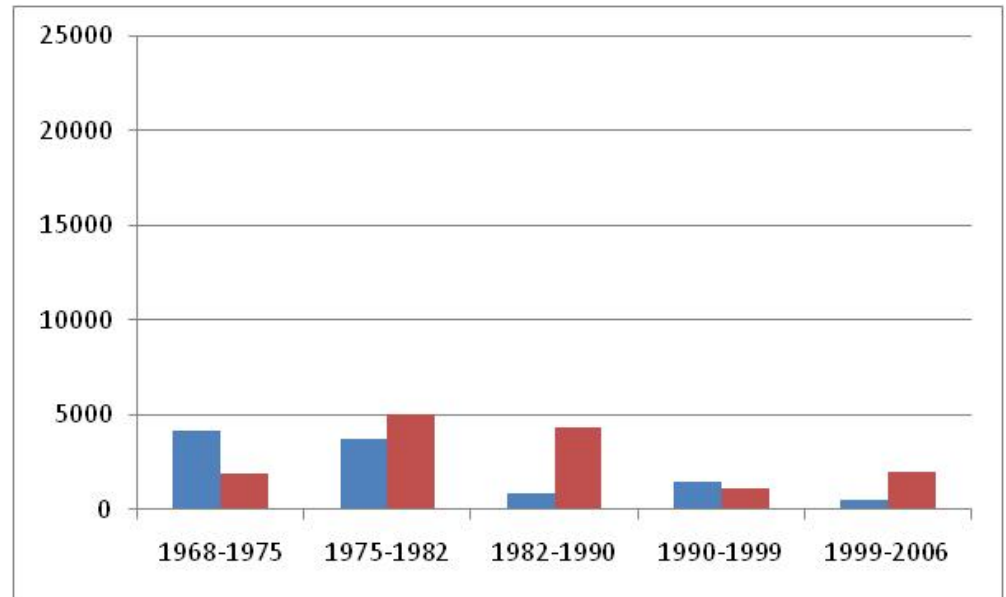

Strasbourg

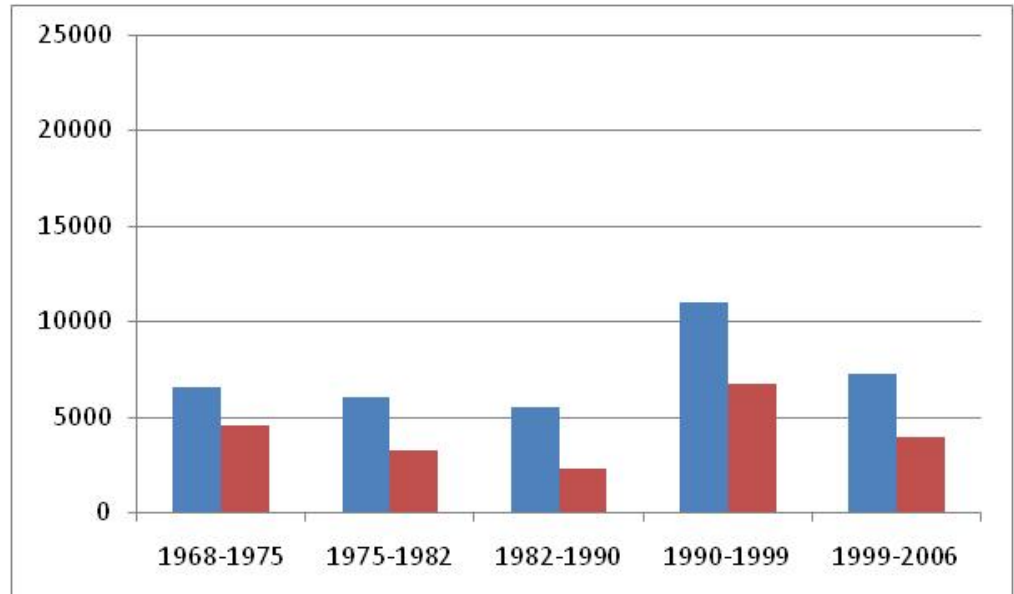




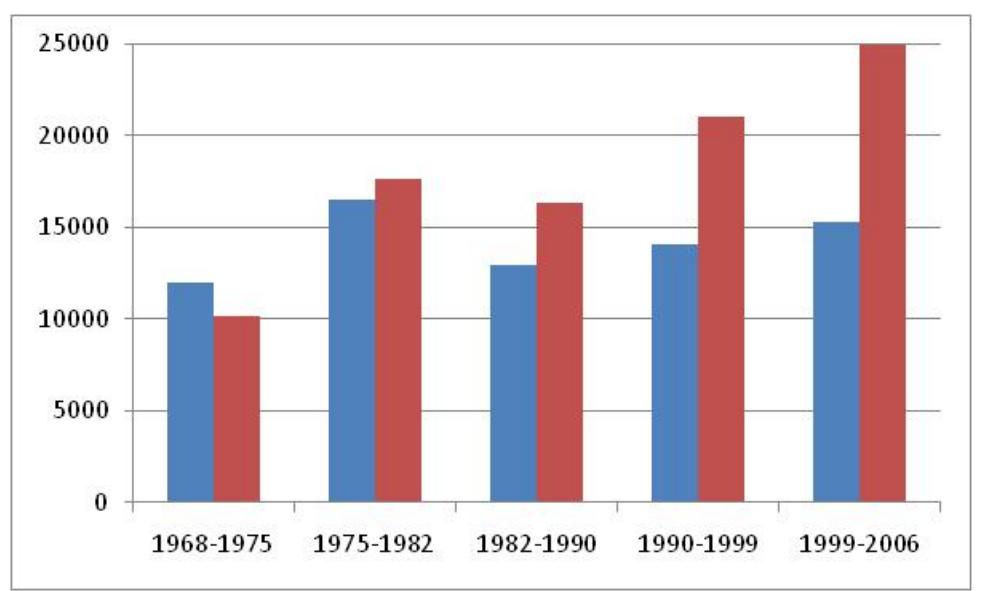

\section{Share of population growth}

\section{- Périurbain, dans corridor \\ - Périurbain, hors corridor}

Source: Xavier Desjardins, SINTROPHER Workshop Presentation, Kassel, September 2012

This brings us back to the 'Heineken model', with the legendary advertising campaign using the slogan 'Heineken refreshes the parts that other beers cannot reach'. Transport planners need to ask: 'How do we refresh the parts that other transport cannot reach?' - in other words, how to develop transport options that reach periurban places? There are two key options: tram-train, and bus rapid transit.

First, tram-trains. Here, the pioneer was Karlsruhe, not far from Freiburg in South West Germany, which pioneered tram-trains in 1992 and has developed a very extensive inter-urban network, with a longest line of 230 kilometres - the S4 tram connecting Baden-Baden, Karlsruhe and Heilbronn some 52 miles away.. It is one of the most remarkable inter-urban transit systems in the world today, and because it has been such a huge success it has become the model for systems in cities elsewhere in Germany and Europe.

One of these is Kassel, an industrial city of 170,000 people in Central Germany, which created on the Karlsruhe model a tram-train system linking a new railway station, opened in 1991 to serve Germany's first high-speed line (opened the same year), and the old station in the city centre, but also serving as an inter-urban system going far 
out into the surrounding countryside, on tracks shared with the heavy-rail trains of the regional rail system. The system opened in August 2007, under the marketing slogan 'RegioTram'10 (Holzapfel, 2012). It is perhaps the ultimate example of what could and should be done in many areas around European medium-sized cities, which are particularly suited to this kind of tram transportation.

And in Strasbourg this is going to happen. It is interesting that in the corner of Europe where Middle Eastern France joins South West Germany and North Central Switzerland there is a series of cities - Strasbourg in France, Basle in Switzerland, Freiburg and Karlsruhe in Germany - which have proved to be highly innovative in different ways, and all of which seem to be learning from each other. Strasbourg was a pioneer in creating a very impressive network of trams, very similar to the Montpellier system; and now it is due to start construction on a tram-train line operating on Karlsruhe/Kassel principles and running onto the rail track of the SNCF and out into the surrounding countryside, into the foothills of the Vosges. And another line may eventually take these tram-trains across the Rhine into Germany, into an international tram-train system.

This brings us back to the Desjardins work. Comparing Kassel with the French cases studied by Desjardins, it is notable that Kassel has consciously developed its land use policies (and not merely in the city of Kassel but in the surrounding Gemeinden), in terms of density, size distribution and rail connectivity, to make the RegioTram a possibility - and also to make regional railways a possibility, through an integrated system of tram-trains and regional railways. The French cities are not so far doing this, with the possible exception now of Strasbourg - a very important lesson of Desjardins' work.

The second 'Heineken' option, bus rapid transit (BRT), has so far received less attention in Europe but has revolutionised urban transit in other parts of the world, especially in Latin America, and also to some degree in Australia. In these places metro systems were developed less often, partly due to cost, and BRT was used instead, first of all some 40 years ago in Curitiba in Brazil, one of the most innovative cities in the world. Curitiba's example has been widely imitated in Latin America, and now the lesson is being learnt in many other places. 
In some ways, Bogotá, capital of Colombia, with a population of 7 million, is the most interesting case of all. It has no metro, but is served by 1,100 red express buses, each carrying up to 270 passengers, linked to green feeder buses, and running along expressways (Hall, 2009). It is an amazing system, created at top speed by a remarkably innovative mayor, Enrique Peñalosa Londoño, in time for the millennium hence the name 'TransMilenio'. It serves very large areas of the city, it is unsubsidised, it is franchised (as in London, although all painted the same colours, the buses are run by private companies), and the density of traffic on the busiest routes equals or exceeds that of many metro systems in the world. An electronic touchcard system is used on the red express buses, and green feeder buses all run free of charge in the neighbourhoods. The TransMilenio is a model for the rest of the world, and it is a model now being followed.

One of the earliest cities to adopt BRT was Adelaide in South Australia 25 years ago, whose guided busway system has now been adopted in Cambridge in England. But in many ways more interesting is the unguided busway operating in Brisbane, Australia, a medium-sized city, very fast growing and setting a remarkable example. Buses run out from the air-conditioned central bus station in the city centre on special bus lanes, often carved out of former dual-carriageways, through intermediate stations offering rail transfer, and onward, running parallel to the freeways, to the termini beyond the city, making it a truly regional system.

BRT can thus serve very wide areas, not only of the built-up agglomeration but also of the entire surrounding region. Curitiba and Bogotá demonstrate that the capacity of these systems approaches that of metros, and that these systems have been cheaper to set up and run. Like tram-based cities, bus-based cities can work and deliver a good high-volume service at low cost. While in the UK the Cambridge guided busway suffered terrible cost escalation, it is now showing traffic figures far in excess of the forecasts - something that does not often happen in public transport forecasting.

But the big question still remains: can tram-trains and BRT services perform the miracle of extending good public transport into wider and wider peripheral areas? The answer is probably not, but there is still a solution here, emerging from work some seven years ago in an EU-funded study called POLYNET (Hall and Pain, 2006), which 
focussed on the larger urban regions across North West Europe, including the South East of England as well as, among others, the Randstad in the Netherlands, and the Rhine-Main area of Germany. In South East England - a region of some 19-20 million people with London, surrounded by 50 other much smaller functional urban regions extending out as far as 130 kilometres from the centre of London, there had been widespread decentralisation, of homes, of people and of jobs out from London to 50 other functional urban regions - city regions - that had grown even faster than in London itself. But there were some interesting surprises. Fig. 4 (a) shows that west of London, there had been a growth in long commuter journeys, often very long journeys, up to 130 kilometres, from places like Peterborough and Bournemouth into Central London - but there had also been a huge growth in criss-cross commuting between the other smaller units. To the east of London there were a few equally long journeys, but almost none of these criss-cross trips. In other words, the area west of London is turning into a complex mega-city region of its own; but as well as being dependent increasingly on long trips to London, it is also developing what one could call a life of its own.

The other surprise is that beyond a 'magic circle' of about 40 or 50 kilometres from Central London, places become increasingly self-contained, even though a minority of people who choose to do so are making long trips every day back into London (Fig. 4 (b)). This is probably a pattern that is developing widely across Europe - certainly in the Stockholm region, as noted above.

Maybe, if we allow the market to work - or better still if we help the market through strong planning policies that encourage more development to take place along strong public transport corridors (inter-city rail corridors) - we can cater for those longerdistance minority journeys while at the same time creating a pattern in which most people live and work locally. However, this would leave one remaining problem: those peripheral urban areas, discussed above. 
Fig. 4 South East Mega-City Region: (a) Commuting journeys, 2001; (b) Self-Containment, 2001
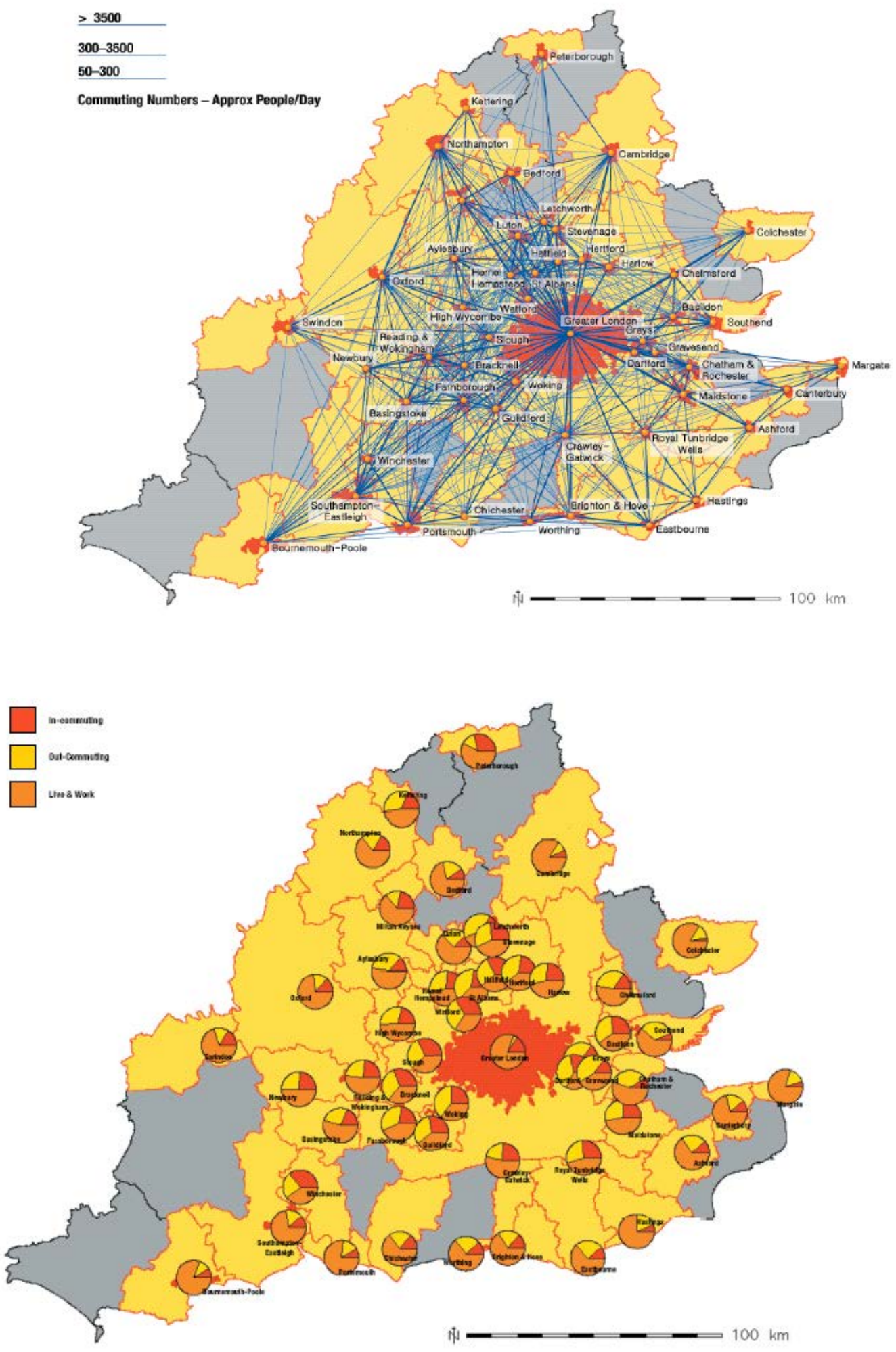

Source: Hall and Pain, 2006 
In summary: a pattern of growth plus deconcentration seems to be a fact of life in Europe and in other OECD countries. The key challenge is to serve the periphery, the peri-urban areas, by sustainable public transport. One answer is tram-trains and BRT along strong transport and land use corridors - what the Californian urban planner Peter Calthorpe calls transit-oriented developments (TODs). The second is in the largest metropolitan areas - the mega-city regions that are growing up; around London, around Paris, around Amsterdam, around Frankfurt - to develop more distant cities through urban extensions and encourage self-containment in those areas. This would still leave the problem of those sometimes long journeys between those other 50 places in South East England and their equivalents in other parts of Europe. Perhaps that S4 tram in Karlsruhe does provide an eventual answer for those places, too. But that could take quite few years to achieve.

\section{References}

Desjardins, X. (2012). 'About the territorial conditions of regional tram systems. Some case studies in France'. SINTROPHER Workshop Presentation, Kassel, Germany, Sept. 2012.

www.sintropher.eu/sites/default/files/images/editors/Workshops/Kassel 2012/WP2/ Xavier\%20Desjardins.pptx

Frey, W.H. (2012). Population Growth in Metro America since 1980. Putting the Volatile 2000s in Perspective. Metropolitan Policy Program. Brookings Institution, Washington, UC, USA, Mar. 2012. www.brookings.edu/ /media/research/files/papers/2012/3/20\%20population\%20frey 10320 population frey.pdf

Hall, P. (2009). 'A regional metro in the mountains'. Town \& Country Planning, 2009, Vol. 78, Nov., 454-6.

Hall, P and Pain, K. (Eds) (2006). The Polycentric Metropolis: Learning from the MegaCity Regions in Europe. Earthscan. 
Hall, P. (2012): 'Lifestyle lines and dynamic decentralisation'. Town \& Country Planning, 2012, Vol. 81, Mar., 114-5.

Hall, P. (2013). Good Cities, Better Lives: How Europe Discovered the Lost Art of Urbanism. Routledge (forthcoming).

Holzapfel, H. (2012). 'The city that came out of the shadows'. Town \& Country Planning, 2012, Vol. 81, Mar., 135-8

Littlefield, M. and Nash , A. (2008) Commuting Patterns as at the 2001 Census, and their Relationship with Modes of Transport and Types of Occupation. Office for National Statistics.

http://neighborhood.statistics.gov.uk/HTMLDocs/images/Commuting\%20by\%200ccup ation\%20and\%20Transport\%20-\%20Final\%20for\%20pdf tcm97-70153.pdf

The Mayor's Outer London Commission: Report. Mayor of London, Jun. 2010 Veltz, P. (2004). Mondialisation, Villes et Territoires: l'économie d'archipel. Presses Universitaires de France, Paris, 1996; and D. Dorling and B. Thomas: People and Place 2001: A Census Atlas. Policy Press-

Vine, S. Le and Jones, P. (2012). On the Move: Making Sense of Car and Train Travel Trends in Britain. RAC Foundation/Office of Rail Regulation/Independent Transport Commission/Transport Scotland, Dec. 2012.

www.racfoundation.org/assets/rac foundation/content/downloadables/on the mov e-le vine \& jonesdec2012.pdf 